\title{
ANALISIS ISI TOPIK DISKUSI INTERAKTIF MAHASISWA UNIVERSITAS TERBUKA DALAM FITUR "FORUM KOMUNITAS UT ONLINE" (Content Analysis Interactive Discussion Topic Open University in Fitur "Forum Komunitas UT Online")
}

\author{
Pardamean Daulay \\ FISIP Universitas Terbuka Surabaya \\ Email: pardamean@mail.Upbjj.ut.ac.id
}

\begin{abstract}
One of problems faced by institution which carries out long distance learning system is lack interaction between students with lecturer. To solve this problems, universitas terbuka (UT) where media internet condeneted a facility of community forum service in UT website. This research aim is to descript UT student interaction pattern in community forum, during registration 06.2 until 07.1. This research is using qualitative description by applying content analysis approach. Result of research shows that there are 1201 email, with 1293 problem, which submitted by 479 students, the most intensive problem is interaction personal (25,90\%), general issue $(14,24 \%)$ score or examination $(11,91 \%)$, tutorial $(25,90 \%)$, module (6,58\%), learning material substance (4,08\%), the way learning $(4,08 \%)$, TAP/UKP (4,00\%), TM/ML (3,41\%), registration (3,41\%), graduation $(2,33 \%)$, curriculum (1,58\%), accreditation (1,58\%), scholarship (0,92\%), school fee (0,58\%), credit switching $(0,42 \%)$, and diploma $(0,17 \%)$.
\end{abstract}

Keywords: Pattern interaction, community forum, UT Online, topic discussion, student characteristic.

\section{PENDAHULUAN}

Dewasa ini penyelenggaraan pendidikan melalui Sistem Belajar Jarak Jauh (SBJJ) tidak lagi menjadi pertanyaan atau dipertanyakan. Masyarakat mulai melihat SBJJ sebagai bagian dari sistem penyelenggaraan pendidikan yang berkualitas, dan bukan sekedar sistem darurat yang dibutuhkan hanya karena desakan keadaan, melainkan karena tuntutan zaman. Kecenderungan tersebut terlihat jelas dengan munculnya gagasan pengembangan dual mode university pada beberapa universitas negeri yang memiliki kredibilitas tinggi seperti ITB, UGM, UI, UNIBRAW, UPI, dan terakhir Universitas Negeri Malang. Bahkan, Depdiknas Propinsi Jawa Timur sedang merencanakan pembukaan program pendidikan jarak jauh dalam menyongsong pelaksanaan program sertifikat guru sesuai dengan amanat Undang-Undang Guru dan Dosen (Jawa Pos, 11 Juli 2006).

Di sisi lain, institusi penyelenggara pendidikan jarak jauh masih memiliki kelemahan dalam mengatasi persoalan interaksi antara mahasiswa dengan dosen. Padahal interaksi dalam proses belajar mengajar merupakan sebuah kebutuhan yang memungkinkan mahasiswa untuk mengetahui hasil belajar yang sedang 
mereka tempuh dan sekaligus memperbaiki kesalahan yang mereka lakukan. McSaac dan Gunawardana (1996) dalam Padmo (2004) menyatakan bahwa pendidikan terbuka dan jarak jauh sebaik pendidikan konvensional (tatap muka). Berkenaan dengan itu, Moore dan Kearsley (1995), membagi tiga tipe interaksi yang esensial dalam pendidikan jarak jauh (PJJ), yaitu pertama interaksi mahasiswa dengan barang ajar, kedua interaksi mahasiswa dengan dosen atau tutor dan ketiga interaksi mahasiswa dengan mahasiswa. Hal ini sangat disadari oleh penyelenggara PJJ, walaupun salah satu karakteristik PJJ adalah adanya keterpisahan antara pengajar dan mahasiswa namun bantuan belajar yang bersifat interaktif tetap dibutuhkan (Keegan dalam Andriani, 2003).

Kendala kurangnya interaksi antara mahasiswa dan dosen dapat dijembatani dengan pemanfaatan perkembangan teknologi informasi dan komunikasi (telematika), khususnya keberadaan jaringan internet yang memungkinkan terjadinya komunikasi dua arah. Kristiadi (2003), menyatakan bahwa pembelajaran melalui media internet dapat didesain agar lebih komunikatif dan interaktif, sehingga mampu meningkatkan kualitas pembelajaran serta memperluas jangkauan dan cakupan, terutama untuk sasaran kelompok masyarakat berbeda melalui sistem pembelajaran berbasis internet (e-learning) atau virtual learning. Melalui jaringan internet mahasiswa dimungkinkan melakukan interaksi dengan mahasiswa lainnya maupun dengan dosen secara jarak jauh dan juga dimungkinkan adanya umpan balik mahasiswa terhadap proses dan hasil belajar mahasiswa.

Universitas terbuka (UT) sebagai satu-satunya Perguruan Tinggi Jarak Jauh (PTJJ) di Indonesia telah melakukan inovasi pembelajaran dengan menggunakan jaringan Internet. Pengembangan layanan komunikasi melalui jaringan internet ini telah dilakukan sejak tahun 1996 melalui fasilitas website UT (Tim Uji Coba UT Online, 2002). Website UT terdiri dari tiga kolom atau fitur, yaitu menu UT, menu UT Online dan menu pendukung. Pada fitur menu UT Online terdapat dua fasilitas layanan belajar yang dapat digunakan oleh mahasiswa. Untuk berkomunikasi baik antar mahasiswa maupun dengan tenaga pengajar, yaitu forum komunitas dan tutorial online. Tutorial online diperuntukkan bagi mahasiswa yang membutuhkan pendalaman materi kuliah dan yang mengikutinya akan memperoleh nilai sebesar $15 \%$ yang diakumulasikan dengan nilai UAS. Sementara, forum komunitas merupakan layanan bantuan belajar dalam bentuk penyediaan sarana diskusi antar mahasiswa, yang dikemas melalui surat elektronik (mailing list). Mailing list adalah perluasan dari e-mail dimana seseorang dapat mengirim pesan kepada sekelompok orang tertentu yang telah terdaftar untuk bergabung dalam kelompok diskusi. Kelompok diskusi yang terbentuk di dunia maya lebih dikenal dengan forum komunitas virtual (Bungin, 2006).

Berbeda dengan forum atau milis yang sengaja dibuat oleh orang-orang yang mempunyai kepentingan yang sama untuk bertemu dalam suatu pembicaraan santai, dimana para anggotanya dapat berasal dari golongan mana saja dan dapat melontarkan pertanyaan atau jawaban tentang berbagai hal yang menyangkut masalah yang diminta. Forum komunitas UT Online ini dirancang khusus sebagai media komunikasi antara mahasiswa UT dalam bentuk diskusi interaktif atau tukar informasi, pemikiran, saran, dan lainnya yang menyangkut kepentingan mereka selama kuliah di UT. Dengan demikian, layanan forum komunitas ini setidaknya memiliki beberapa tujuan, antara lain pertama, mahasiswa dapat melakukan interaksi secara bebas dengan mahasiswa satu program studi atau dengan maha- 
siswa di luar program studinya, kedua, mahasiswa dapat bertukar informasi (sharing) atau berdiskusi tentang masalah perkuliahan di UT, materi kuliah yang dirasa kurang jelas, dan masalah yang sifatnya lebih pribadi, ketiga, mahasiswa dapat membentuk group atau kelompok (social formation) berdasarkan preferensi yang sama, keempat, membantu proses belajar mandiri, dan kelima, dapat memperoleh umpan balik atas berbagai masalah yang ditanyakan secara efisien, efektif, dan lebih murah.

Artikel ini membahas penelitian yang bertujuan untuk menganalisis isi diskusi interaktif mahasiswa UT yang termuat dalam forum komunitas FISIP UT selama masa registrasi 2006.2 sampai dengan 2007.2. Melalui analisis ini diharapkan dapat diperoleh: (1) kecenderungan topik yang menjadi bahan diskusi interaksi, dan (2) sebaran mahasiswa pengguna forum komunitas.

Penelitian ini diharapkan dapat memberikan sumbangan pengetahuan untuk pelayanan akademik yang lebih baik bagi mahasiswa UT sebagai institusi penyelenggaraan PJJ di Indonesia khususnya dan bagi seluruh institusi penyelenggaraan PJJ pada umumnya. Hasil penelitian ini juga diharapkan dapat memperkaya peranan media internet dalam pembelajaran terutama bagi universitas tatap muka yang ingin mengembangkan inovasi pembelajaran melalui jaringan internet (e-learning).

Unit analisis yang dijadikan bahan kajian dalam penelitian ini adalah unit tematik, yaitu berupa topik diskusi dan tanggapan yang termuat dalam forum komunitas FISIP UT, yang berisi tentang berbagai masalah mahasiswa selama menjalani perkuliahan di UT. Isi topik diskusi interaktif mahasiswa diklasifikasikan menjadi tiga kategori yaitu informasi akademik, informasi administrasi dan informasi lainlain, sebagaimana tampilan Tabel 1.

Tabel 1. Kategorisasi isi topik diskusi mahasiswa dalam forum komunitas FISIP UT

\begin{tabular}{|c|c|c|}
\hline Unit Analisis & $\begin{array}{c}\text { Kategori Topik } \\
\text { Diskusi }\end{array}$ & Sub Kategori Topik Diskusi \\
\hline \multirow[t]{3}{*}{$\begin{array}{l}\text { Isi informasi tentang } \\
\text { diskusi interaktif } \\
\text { pada "Forum Komu- } \\
\text { nitas FISIP-UP" }\end{array}$} & Administrasi & $\begin{array}{l}\text { - Proses registrasi } \\
\text { - Masa/waktu ujian } \\
\text { - Kalender akademik } \\
\text { - Pindah lokasi ujian } \\
\text { - Nilai ujian } \\
\text { - Nilai praktikum } \\
\text { - Nilai TAP } \\
\text { - Tugas Mandiri } \\
\text { - Pindah UPBJJ } \\
\text { - Informasi alih kredit }\end{array}$ \\
\hline & Akademik & $\begin{array}{l}\text { - Ketersediaan modul } \\
\text { - Pemilihan mata kuliah } \\
\text { - Kegiatan tutorial } \\
\text { - Kesulitan belajar } \\
\text { - Modul belajar mandiri }\end{array}$ \\
\hline & Lain-lain & $\begin{array}{l}\text { - Pembentukan social formation } \\
\text { - Perkenalan } \\
\text { - Kegiatan sosial }\end{array}$ \\
\hline
\end{tabular}


Pengumpulan data dilakukan dengan dua tahap. Pertama, mengumpulkan semua topik diskusi interaktif mahasiswa yang terekam dalam forum komunitas FISIP UT selama enam bulan atau selama masa registrasi 2006.2 sampai dengan 2007.1 Langkah awal yang dilakukan untuk memperoleh topik-topik diskusi interaktif mahasiswa adalah mendaftar sebagai anggota forum komunitas. Kedua, melakukan analisis isi terhadap semua topik diskusi interaktif mahasiswa secara deskriptif kualitatif dengan menggunakan tabel frekuensi. Langkah-langkah analisis data dilakukan dengan mengacu kepada pendapat Miles dan Huberman (1992), yang membagi tiga alur kegiatan analisis data dan dilakukan secara bersamaan yaitu: reduksi data, penyajian data, dan penarikan kesimpulan.

\section{PEMBAHASAN}

\section{Interaksi Mahasiswa PJJ dalam Fitur Forum Komunitas UT Online}

Terdapat banyak definisi yang mencoba mendeskripsikan Pengertian Pendidikan Jarak Jauh (PJJ). Namun terkait dengan tema penelitian pada artikel ini, maka definisi pendidikan jarak jauh mengacu pada pendapat Keegan (1991) yang mengidentifikasi 6 (enam) karakteristik dari konsep pendidikan jarak jauh, yaitu: (1) adanya keterpisahan antara dosen dengan mahasiswa, di mana konsep inilah yang membedakan antara PJJ dengan pengajaran tatap muka, (2) ada pengaruh dari suatu organisasi atau institusi pendidikan dalam hal belajar yang membedakannya dengan belajar sendiri di rumah, (3) adanya penggunaan beragam media (cetak dan non-cetak) untuk mempersatukan dosen dan mahasiswa dalam suatu interaksi pembelajaran, (4) adanya komunikasi dua arah sehingga mahasiswa dapat menarik manfaat dan melakukan dialog jika diperlukan, (5) kemungkinan ada pertemuan sesekali untuk keperluan pembelajaran dan sosialisasi, serta (6) ada proses pendidikan yang memiliki bentuk hampir sama dengan proses yang terdapat dalam industri.

Definisi di atas memperlihatkan bahwa sistem pendidikan jarak jauh (SPJJ) mempunyai ciri khusus tidak adanya perkuliahan tatap muka antara dosen dengan mahasiswanya. Untuk menjembatani terpisahnya jarak antara tenaga pengajar dengan mahasiswa, maka dilakukan dengan penggunaan berbagai media dalam proses pembelajarannya. Mahasiswa belajar secara mandiri melalui berbagai media komunikasi dalam skala luas dan berjarak jauh yang difasilitasi oleh pengelola pendidikan. Mahasiswa dapat mengambil inisiatif untuk memanfaatkan perpustakaan, mengikuti siaran radio, mengikuti tutorial serta menggunakan sumber belajar lain seperti bahan ajar berbantuan komputer dan program audio/video. Dengan demikian, belajar mandiri menghendaki mahasiswa untuk belajar atas prakarsa atau inisiatif sendiri.

Website UT dapat diakses di alamat www.ut.ac.id secara umum terbagi dalam tiga kolom yaitu kolom paling kiri yang disebut (bertitel) menu utama, kolom tengah yang disebut informasi umum dan kolom paling kanan yang disebut menu pendukung. Masing-masing kolom tersebut terdiri dari beberapa fitur. Forum Tanggapan merupakan salah satu fitur yang ada pada kolom Menu Utama yang merupakan fitur dengan urutan ketiga. Pembahasan dalam penelitian ini terbagi dalam dua kelompok besar yaitu karakteristik demografi responden dan conten analisis isi surat email yang ditujukan ke "Forum Tanggapan"

Tampilan (interface) Website UT, pada dasarnya terbagi ke dalam 5 (lima) menu utama, yaitu; menu UT Online, menu mail, menu kalender, menu info akademik, 
dan menu informasi hukum. Kelima menu utama tersebut ditempatkan secara terpisah sesuai dengan klasifikasi masing-masing. Pada kolom paling kiri terdapat menu UT Online, kolom tengah ditempati menu mail, menu kalender, dan menu info akademik, sementara pada kolom paling kanan terdapat menu info umum.

Menu UT Online, pada prinsipnya, merupakan layanan bantuan belajar berbasis internet atau yang sering disebut "learning center" ataupun e-learning. Melalui UT Online, seorang mahasiswa dapat mengakses informasi umum dan informasi layanan akademik. Informasi umum terdiri dari informasi umum dan berita-berita aktual UT, program pendidikan yang ditawarkan UT, cara registrasi, dan kalender akademik. Sementara itu, layanan akademik memuat materi suplemen online, naskah latihan mandiri, tutorial online, nilai ujian akhir semester (DNU Online), LKAM Online, Ujian Online, Video Online, Jurnal Elektronik, Abstrak hasil penelitian, perpustakaan Online, dan Forum Komunitas.

Proses berlangsungnya interaksi antara mahasiswa dalam forum komunitas FISIP UT ternyata tidak berbeda dengan proses interaksi dalam kehidupan sosial yang nyata. Proses berlangsungnya interaksi antara mahasiswa diawali dengan pemberian stimulus (informasi) oleh salah seorang mahasiswa dan kemudian berlanjut dengan adanya respon (tanggapan) dari mahasiswa lain. Bila terjadi kecocokan, interaksi terus berlanjut dan menghasilkan diskusi interaksi yang mendalam. Sebaliknya, bila tidak ada interaksi juga terputus bila sesama anggota forum merasa topik diskusi sudah jelas atau up to date lagi.

Sebagai sebuah komunitas, kehidupan sosial yang terjadi pada forum komunitas FISIP UT memiliki pranata tersendiri yang dibangun secara bersama sebagai sistem proteksi diri. Kehadiran setiap anggota diatur dan dikontrol agar tidak mengganggu dan merusak jaringan (order) yang ada karena forum komunitas dibangun melalui teknologi media yang disimpan dalam kotak-kotak harddisk dan server yang sangat rentang terhadap berbagai macam kerusakan fisik maupun kerusakan karena perangkat program virus. Website UT tidak mengijinkan orang lain mengakses ke dalam fasilitas tertentu apabila tidak menggunakan password Karena itu, mahasiswa yang ingin menggunakan layanan forum komunitas ini. harus terlebih dahulu mendaftar atau login. Persyaratan utama diterima sebagai anggota forum adalah harus memiliki alamat $e$-mail yang dikirimkan ke pengelola website UT, dan tentunya harus memiliki NIM (Nomor Induk Mahasiswa). Setelah itu, barulah mahasiswa dapat bergabung pada forum komunitas.

Hasil penelitian ini menunjukkan bahwa mahasiswa FISIP-UT yang telah memanfaatkan fasilitas Forum Komunitas selama masa registrasi 2006.2 s.d 2007.2 adalah 479 orang yang terdiri dari 218 orang sebagai pengguna pada masa registrasi 2006.2 dan 261 orang pada masa registrasi 2007.1 Dengan demikian mahasiswa pengguna fasilitas forum komunitas sangat sedikit bila dibandingkan dengan jumlah keseluruhan mahasiswa FISIP-UT yang masih aktif. Data BAAPM Universitas Terbuka menunjukkan bahwa jumlah mahasiswa aktif FISIP-UP sampai dengan masa registrasi 2007.1 adalah 34.174 orang, dengan perincian Program Studi Administrasi Negara 12.345 orang, Administrasi Niaga 2.410 orang, Ilmu Pemerintahan 4.820 orang, D-2 Perpajakan 1.176 orang, D-2 Perpustakaan 761 orang, Ilmu Komunikasi 6.360 orang, Sosiologi 3.960 orang dan D-3 Penerjemahan 2.342 orang. Dengan kata lain, jumlah mahasiswa FISIP-UT yang telah memanfaatkan forum komunitas sampai masa 2007.1 baru mencapai 0,13\% dari keseluruhan mahasiswa FISIP-UP. Kecilnya persentase mahasiswa yang telah menggunakan forum komunitas ini dapat berarti bahwa, pertama forum komunitas ini relatif baru maka 
mahasiswa yang mengakses relatif masih sedikit; kedua, kurangnya sosialisasi secara meluas, ketiga mahasiswa mungkin telah mengetahui tetapi karena di daerah tempat tinggalnya akses internet relatif sulit dan kalaupun ada relatif mahal, maka mahasiswa lebih memilih tidak terlalu sering mengakses website UT dan hanya akan mengakses jika hal itu benar-benar penting bagi mereka.

Dilihat dari karakteristik jenis kelamin, mahasiswa yang telah terjaring sebagai pengguna forum komunitas FISIP UT mayoritas adalah laki-laki, yaitu sebesar 325 orang $(67,85 \%)$, sedangkan user perempuan berjumlah 154 orang $(32,15 \%)$. Sementara itu, dari segi usia, mayoritas mahasiswa pengguna forum komunitas berusia antara 21-30 tahun sebanyak 250 orang (52,19\%), mereka yang berusia 31-40 tahun berjumlah 150 orang $(31,31 \%)$, sedangkan mereka yang berusia di atas 40 tahun sebesar 79 orang $(16,50 \%)$. Bila dibandingkan dengan usia rata-rata mahasiswa baru yang terdapat di berbagai perguruan tinggi tatap muka pada setiap angkatan, maka usia mahasiswa UT relatif heterogen dan mayoritas berada pada kategori umur 30 tahun ke bawah. Hal ini menunjukkan bahwa sebagian besar mahasiswa UT adalah usia produktif yang diprediksikan sudah bekerja. Dengan demikian, mahasiswa pengguna Forum Komunitas FISIP-UT sebagian besar sudah bekerja. Temuan ini didukung hasil penelitian yang dilakukan Andayani (2005) yang menunjukkan bahwa sebagian besar mahasiswa UT memanfaatkan fasilitas internet di tempat bekerja mereka masing-masing.

Pengguna Forum Komunitas FISIP-UT adalah mahasiswa yang berasal dari berbagai program studi di lingkungan FISIP-UT. Dari 479 mahasiswa yang terdata melakukan akses pada forum, ternyata jumlah mahasiswa yang berasal dari Program Studi Ilmu Komunikasi sebanyak 161 orang (33.61\%), Program Studi Bahasa Inggris Penerjemahan 137 orang (28.60\%), Program Studi Ilmu Pemerintah 65 orang (13.57\%), Program Studi Administrasi Niaga 35 orang (7.31\%), Program Studi D-3 Perpajakan 33 orang (6.89\%), Program Studi Administrasi Negara 31 orang (6.47\%), Program Studi Sosiologi 11 orang (2.30\%), dan yang paling kecil jumlahnya adalah Program Studi D-2 Perpustakaan sebanyak 6 orang (1.25\%). Gambaran sebaran pengguna Forum Komunitas FISIP-UT masa registrasi 062-071 dapat dilihat pada Tabel 2 .

Tabel 2. Sebaran Program Studi Pengguna Forum Komunitas FISIP-UT*)

\begin{tabular}{clcccc}
\hline No & \multicolumn{1}{c}{ Jurusan/Program } & $\mathbf{0 6 . 2}$ & $\mathbf{0 7 . 1}$ & & $\mathbf{\%}$ \\
\hline 1 & Ilmu Komunikasi & 84 & 77 & 161 & 33.61 \\
2 & Bahasa dan Sastra & 63 & 74 & 137 & 28.60 \\
3 & Ilmu Pemerintahan & 24 & 41 & 65 & 13.57 \\
4 & Administrasi Niaga & 10 & 21 & 35 & 7.31 \\
5 & Perpajakan & 9 & 24 & 33 & 6.89 \\
6 & Administrasi Negara & 19 & 16 & 31 & 6.47 \\
7 & Sosiologi & 6 & 5 & 11 & 2.30 \\
8 & Perpustakaan & 3 & 3 & 6 & 1.25 \\
\hline Total Users Mhs FISIP-UT & $\mathbf{2 1 8}$ & $\mathbf{2 6 1}$ & $\mathbf{4 7 9}$ & $\mathbf{1 0 0}$ \\
\hline \multicolumn{2}{r}{ Total Users } & & $\mathbf{4 8 9}$ & \\
\hline
\end{tabular}

*) 489 users itu termasuk alumni 7 orang dan mhs Manajemen Fekon 3 orang (jumlah users yang akses ke website UT adalah 479).

Sumber: Diolah dari hasil pengumpulan data 


\section{Analisis Isi Topik Diskusi Interaktif Mahasiswa FISIP UT}

Hasil identifikasi dari isi perbincangan mahasiswa FISIP-UT di dalam Forum Komunitas FISIP-UT, pada prinsipnya mencakup masalah-masalah yang menyangkut registrasi, tutorial, modul (termasuk substansi/materi modul), ujian dan nilai ujian baik UAS maupun TAP/UKT serta mengenai Tugas Mandiri/Lembar Mandiri (TM/LM). Selain itu juga para mahasiswa memperbincangkan mengenai masalah yang menyangkut yudisium, wisuda, ijasah, alih kredit dan kurikulum, akreditasi, biaya kuliah, beasiswa, serta diskusi lainnya mengenai hal-hal yang dianggap aktual oleh mahasiswa. Mahasiswa juga ternyata mendiskusikan berbagai isu aktual yang terjadi di masyarakat. Tabel 3 menggambarkan berbagai masalah yang menjadi bahan diskusi interaktif mahasiswa pada forum komunitas FISIP-UT.

Tabel 3. Sebaran Topik Diskusi Mahasiswa dalam Forum Komunitas FISIP-UT

\begin{tabular}{|c|c|c|c|c|c|c|c|c|c|c|c|c|c|c|}
\hline \multirow{2}{*}{ Topik diskusi } & \multicolumn{7}{|c|}{ 2006. 2} & \multicolumn{5}{|c|}{ 2007. 1} & \multirow{2}{*}{$\Sigma$} & \multirow{2}{*}{$\%$} \\
\hline & Jun & Juli & Ags & Sep & Okt & Nov & Des & Jan & Peb & Mar & Apr & Mei & & \\
\hline Registrasi & & & 6 & 4 & 2 & 1 & & 3 & 3 & 11 & 11 & & 41 & 3.41 \\
\hline Tutorial & & & 12 & 13 & 12 & 12 & & 5 & 11 & 45 & 14 & 8 & 132 & 10.99 \\
\hline Modul & 3 & & 5 & 19 & 7 & 1 & 2 & & 10 & 20 & 11 & 1 & 79 & 6.58 \\
\hline Substansi materi & & 1 & & 1 & 8 & 5 & 3 & 3 & 4 & 8 & 15 & 1 & 49 & 4.08 \\
\hline Nilai ujian & 11 & 11 & 12 & 10 & 4 & 5 & 1 & 49 & 10 & 5 & 22 & 3 & 143 & 11.91 \\
\hline Yudicium & & & 4 & & & & & & 8 & 4 & & & 16 & 1.33 \\
\hline Wisuda & & & & 3 & & & 1 & & & 3 & 19 & 3 & 28 & 2.33 \\
\hline Biaya Kuliah & & & & 3 & & 2 & & 1 & & 1 & & & 7 & 0.58 \\
\hline TAP/UKT & 3 & & 9 & 5 & 1 & 7 & & 8 & 4 & 9 & 1 & 1 & 48 & 4.00 \\
\hline Cara Bljr & & 4 & 3 & 9 & 6 & 8 & 1 & 9 & 5 & 7 & 5 & & 57 & 4.75 \\
\hline Kurikulum & 2 & 1 & & & & & & 2 & & 14 & & & 19 & 1.58 \\
\hline Alih Kredit & & 1 & & & & 3 & & & & & 1 & & 5 & 0.42 \\
\hline Akreditasi & & & & & 5 & & & 14 & & & & & 19 & 1.58 \\
\hline Ijasah & & & & & & & & & & 2 & & & 2 & 0.17 \\
\hline TM/LM & & & 1 & 10 & 11 & & & 6 & & 8 & 4 & 1 & 41 & 3.41 \\
\hline Bea Siswa & & & & & & 3 & 8 & & & & & & 11 & 0.92 \\
\hline Kegiatan Kmhswn & 1 & 1 & & 4 & & & & 7 & & 6 & 2 & & 21 & 1.75 \\
\hline Interaksi personal & 16 & 6 & 3 & 21 & 15 & 6 & 4 & 61 & 9 & 109 & 55 & 6 & 311 & 25.90 \\
\hline Lain-lain & 12 & 4 & 6 & 6 & 18 & 2 & 21 & 26 & 6 & 29 & 36 & 5 & 171 & 14.24 \\
\hline Total & 48 & 29 & 61 & 108 & 89 & 55 & 41 & 194 & 70 & 281 & 196 & 29 & 1201 & 100 \\
\hline
\end{tabular}

Dari hasil identifikasi yang telah dilakukan, total $e \_$mail yang masuk dalam forum komunitas FISIP-UT selama masa registrasi 2006.2 s.d 2007.1 adalah 1201 e_mail yang meliputi 1.293 'persoalan'. Jumlah ini lalu dipilih dan dikategorikan ke dalam tiga topik utama dengan perincian 418 e_mail (34.80\%) yang bersifat PERTANYAAN (questions) yang mencakup permintaan, usulan, himbauan, dan ajakan, 635 e_mail (52.87\%) yang bersifat PERNYATAAN (statements) termasuk informasi, deklarasi, dan ajakan. Sedangkan jawaban yang dapat dikategorikan sebagai JAWABAN atau SOLUSI (solutions) atas pertanyaan dan kritik sebanyak 148 (12.32\%). Namun, untuk kepentingan penelitian, e_mail yang termasuk dikelompokkan menjadi 3 (tiga) kategori topik diskusi, yaitu topik diskusi yang bersifat administratif, topik diskusi yang bersifat akademik, dan topik diskusi lainlain. Tabel 4 menunjukkan kecenderungan topik diskusi mahasiswa UT pada Forum Komunitas FISIP UT Online. 
Tabel 4. Kategorisasi Topik Diskusi dalam Forum Komunitas FISIP UT serta Persentasi Per Kategori Topik Diskusi

\begin{tabular}{|c|c|c|c|c|c|c|c|}
\hline & \multirow{3}{*}{ Kategori Topik Diskusi } & \multicolumn{4}{|c|}{ Masa Registrasi } & \multirow{2}{*}{\multicolumn{2}{|c|}{ Jumlah }} \\
\hline & & \multicolumn{2}{|c|}{2006.2} & \multicolumn{2}{|c|}{2007.1} & & \\
\hline & & Frek. & $\%$ & Frek. & $\%$ & Frek. & $\%$ \\
\hline \multicolumn{8}{|c|}{ 1. Administrasi } \\
\hline & Registrasi & 13 & 12.15 & 28 & 14.97 & 41 & 13.90 \\
\hline & Nilai/Ujian & 53 & 49.53 & 90 & 48.13 & 143 & 48.47 \\
\hline & Yudicium & 4 & 3.74 & 12 & 6.42 & 16 & 5.42 \\
\hline & Wisuda & 4 & 3.74 & 25 & 13.37 & 29 & 9.83 \\
\hline & Biaya Kuliah & 5 & 4.67 & 2 & 1.07 & 7 & 2.37 \\
\hline & Ahli Kredit & 4 & 3.74 & 1 & 0.53 & 5 & 1.69 \\
\hline & TM/LM & 21 & 19.62 & 19 & 10.16 & 40 & 13.56 \\
\hline & Beasiswa & 3 & 2.80 & 8 & 4.28 & 11 & 3.73 \\
\hline & Ijazah & - & - & 2 & 1.07 & 2 & 0.68 \\
\hline & Sub total & 107 & 100 & 187 & 100 & 294 & 100 \\
\hline \multirow[t]{8}{*}{2.} & Akademik & & & & & & \\
\hline & Tutorial & 49 & 31.21 & 83 & 36.56 & 132 & 34.37 \\
\hline & Modul/bhn. Ajar & 35 & 22.29 & 44 & 19.38 & 79 & 20.57 \\
\hline & Substansi & 15 & 9.55 & 34 & 14.98 & 49 & 12.76 \\
\hline & TAP/UKT & 25 & 15.92 & 23 & 10.13 & 48 & 12.50 \\
\hline & Cara Belajar & 30 & 19.10 & 27 & 11.90 & 57 & 14.84 \\
\hline & Kurikulum & 3 & 1.90 & 16 & 7.05 & 19 & 4.94 \\
\hline & Sub total & 157 & 100 & 227 & 100 & 384 & 100 \\
\hline \multirow[t]{6}{*}{3.} & Lain-lain & & & & & & \\
\hline & Akreditasi UT & 5 & 3.93 & 14 & 3.54 & 19 & 3.63 \\
\hline & Keg Kmhswn & 7 & 5.51 & 15 & 3.79 & 22 & 4.21 \\
\hline & Interaksi personal & 67 & 52.76 & 244 & 61.61 & 311 & 59.46 \\
\hline & Pembentukan social formation & 48 & 37.80 & 123 & 31.06 & 171 & 32.70 \\
\hline & Sub total & 127 & 100 & 396 & 100 & 523 & 100 \\
\hline \multicolumn{2}{|c|}{ Total } & & & & & 1201 & 100 \\
\hline
\end{tabular}

Data di atas menggambarkan bahwa topik diskusi interaktif yang masuk ke dalam forum komunitas FISIP dan menjadi bahan perbincangan mahasiswa yang paling intens adalah topik diskusi dengan katagori lain-lain. E_mail yang masuk mengenai masalah ini sebanyak 523 topik $(43,55 \%)$, berikutnya masalah akademik sebanyak 384 e_mail (31.97\%), dan terakhir yang berkaitan dengan masalah administratif sebanyak 294 e_mail (24.48\%).

\section{Masalah lain-lain}

Topik diskusi yang berkategori lain-lain adalah bahasan diskusi diluar lingkup administrasi dan lingkup akademik. Diantara bahasan diskusi tersebut, ternyata perbincangan mahasiswa yang paling menarik adalah mengenai interaksi personal antar mahasiswa (59.46\%). Perbincangan ini seputar kegiatan kelompok atau individu, termasuk memperkenalkan diri, keinginan untuk berkenalan dan melakukan kontak baik dengan internet ataupun melalui telepon pribadi. 


\section{Masalah-Masalah Administratif}

Berdasarkan tingkat intensitas kecenderungan topik diskusi yang bersifat administratif, masalah yang paling banyak ditanyakan atau paling banyak menjadi bahan perbincangan adalah masalah nilai/ujian (48,47\%). Umumnya pertanyaan mahasiswa tentang ujian adalah registrasi ujian, tempat mendapatkan Kartu Tanda Peserta Ujian (KTPU), kapan nilai ujian keluar, mengapa nilai ujian tidak keluar, kebingungan menghadapi ujian UT, bagaimana cara mengakses web UT agar dapat melihat hasil ujian, bagaimana caranya meregistrasi untuk ujian online, sampai 'curhat' karena ujiannya sulit dan nilainya jatuh. Selain itu juga ada usulan supaya UT mengadakan semester pendek agar mereka yang tidak lulus atau lulusannya dengan nilai jelek dapat mengikuti ujian lagi. Para mahasiswa juga membicarakan mengenai masalah Tugas Akhir Program (TAP).

Semua keluhan, pertanyaan, kebingungan, frustasi, ataupun nasihat yang dilontarkan mahasiswa, khususnya yang menyangkut permasalahan seputar ujian, sungguh merupakan hal yang wajar adanya, karena masalah ujian dapat dikatakan merupakan tolok ukur keberhasilan atau ketidakberhasilan proses belajar yang dijalani mahasiswa, sehingga mereka benar-benar menganggap bahwa ujian itu sangat penting. Bagi setiap mahasiswa, dapat dikatakan, bahwa ujian adalah persoalan 'hidup dan mati' mereka. Memang, sampai sejauh ini, ujian merupakan salah satu elemen yang paling krusial di dalam sistem belajar. Secara psikologis, orang akan merasa gagal dalam belajar apabila gagal dalam ujian. Di dalam sistem pembelajaran atau sistem belajar mengajar, evaluasi hasil belajar atau tes merupakan indikator atas berhasil/tidak berhasilnya seseorang dalam menguasai suatu materi (mastery learning).

Topik berikutnya setelah topik ujian yang menjadi perbincangan mahasiswa yaitu permasalahan di seputar registrasi (13,90\%). Bila dicermati apa yang menjadi perbincangan mereka maka sebenarnya masalah ini berkaitan juga dengan masalah ujian. Memang, perbincangan yang dapat di tangkap hampir selalu menyinggung masalah batas waktu atau persyaratan registrasi, tetapi tidak ditarik lebih jauh, maka masalah registrasi ini akan terkait langsung dengan masalah ujian. Di dalam sistem UT, mahasiswa yang tidak dapat melakukan registrasi atau gagal registrasi dengan alasan apapun maka yang bersangkutan akan kehilangan hak untuk menempuh ujiannya pada semester berjalan. Dengan kata lain, mahasiswa merasa kuatir tidak dapat mengikuti ujian apabila registrasinya bermasalah. Jadi, masuk akal bila masalah ini mencuat sebagai masalah yang juga dianggap krusial oleh mahasiswa karena ujian mereka sangat tergantung kepada registrasi matakuliah yang dilakukan oleh yang bersangkutan.

Masalah ini yang juga di singgung dalam perbincangan mereka adalah mengenai masalah seputar yudicium $(5,42 \%)$, wisuda $(9,83 \%)$, biaya kuliah $(2,37 \%)$, alih kredit $(1,69 \%)$, beasiswa $(3,73 \%)$, dan mengenai ijazah $(0,68)$. Meskipun frekuensinya rendah dalam arti intensitasnya tidak tinggi tetapi hal tersebut tidak luput dari perhatian para mahasiswa. Masalah yudicium misalnya, pada umumnya mahasiswa menanyakan mengenai persyaratan untuk dapat ikut yudicium. Bagi mereka, yudicium artinya mengikuti wisuda, upacara penganugrahan gelar kesarjanaan: sesuatu yang memang selama ini mereka perjuangkan.

Tidak banyak mahasiswa yang complain mengenai ijazah yaitu hanya dua buah e_mail atau hanya sebesar $0,38 \%$ sari keseluruhan mahasiswa selama masa registrasi 062-071 ini. Keluhan mereka itu, pertama, adalah mengenai besarnya 
biaya wisuda di daerah ini, di mana mahasiswa yang bersangkutan tidak berniat mengikuti upacara wisuda UT pusat dengan harapan dapat menghemat biaya, ternyata di daerah dipungut biaya yang dirasa cukup mahal dan membebani mahasiswa yang bersangkutan. Di mana hal ini di luar perkiraannya semula. Kedua, adalah mengenai ketentuan UT yang menyangkut foto calon wisudawan dan wisudawati di mana mereka harus menyerahkan foto kelihatan daun telinga. Bagaimana bagi yang memakai jilbab? Begitu persoalannya. Barangkali UT sebaiknya meninjau ulang ketentuan ini atau memberlakukan ketentuan khusus bagi mereka yang berjilbab terkait dengan 'foto kelihatan telinga' karena kecenderungan atau trend sekarang ini banyak wanita yang mengenakan jilbab sehingga akan menjadi isu yang kontroversial apabila ada kebijakan yang mengharuskan wanita harus di foto dengan kehilangan telinga.

Sebagai perguruan tinggi negeri, UT telah diakreditasi oleh Badan Akreditasi Nasional Perguruan Tinggi (BAN-PT). Tetapi sebagai perguruan tinggi yang menerapkan sistem belajar jarak jauh (SBJJ) maka barang kali belum ada instrumen yang 'pas' untuk mengakreditasi UT oleh karenanya UT sebagai PTJJ kelihatannya 'belum tersentuh' oleh akreditasi BAN-PTJJ (dan bukan sekedar banpt). Perlu barangkali pemerintah memikirkan instrumen akreditasi yang sesuai dengan karakteristik UT untuk efektivitas dan efisien UT sebagai perguruan tinggi yang menerapkan sistem pendidikan jarak jauh. Oleh karenanya, sejak tahun 2004 UT berupaya memperoleh sertifikat ISO 9001:20001

Perbincangan mahasiswa di atas setidaknya memberikan informasi kepada kita bahwa akreditasi UT dimata mahasiswa sendiri masih sangat rendah. Untuk itu, perlu juga dilakukan kajian tentang image (citra, gambar, persepsi) dan juga mengenai awareness (sejauh mana pengetahuan) masyarakat terhadap UT., terutama mengetahui keberadaan UT setelah memperoleh penghargaan dari ICDE, ISA dan perolehan ISO 90001:2000. Harus ada kajian mengenai image dan awareness masyarakat mengenai kiprah dan peran UT sampai sekarang ini. Sebab dengan penghargaan tersebut, seharusnya dapat 'membuka mata' masyarakat awam serta dapat mendongkrak 'nilai jual' UT di masyarakat.

\section{Masalah-Masalah Akademik}

Topik bahasan yang bersifat akademik, mencakup masalah-masalah di sekitar tutorial, modul/bahan ajar, substansi modul, TAB/UKT, Cara belajar, serta kurikulum.

\section{1) Tutorial}

Masalah yang juga begitu intens diperbincangkan mahasiswa adalah mengenai tutorial. Tutorial (tutorial elektronik maupun tutorial tatap muka) menjadi topik yang banyak menjadi sorotan di mana $34.37 \%$ dari seluruh mahasiswa yang diamati memperbincangkan dan mempersoalkan mengenai tutorial. Masalah-masalah yang diamati persoalan mahasiswa diantaranya mencakup aksesibilitas ke dalam situs

\footnotetext{
1 Sertifikasi ISO 9001:2000 adalah sertifikasi untuk manajemen internal ketika tulisan ini dibuat UT telah memperoleh Sertifikat ISO 9001:2000 untuk Bahan Ajar dan Bahan Ujian serta ISO 9001:2000 untuk UPBJJ. Unit yang memperoleh ISO 9001:2000 Bahan Ajar dan bahan Ujian adalah FEKON, FKIP, FISIP, FMIPA, PUSLABA, PPBAC, PPBANC, PUSJIAN. Sedangkan untuk ISO UPBJJ yang memperolehnya adalah UPBJJ-UT Palembang, UPBJJ-UT Bogor, UPBJJ-UT Bandung, UPBJJ UT Purwokerto, UPBJJUT Yogyakarta, dan UPBJJ-UT Surabaya.
} 
UT, khususnya akses ke materi tutorial. Sebagian mahasiswa merasa kecewa dengan penyelenggaraan tutor di FISIP, sementara sebagian lagi mempertanyakan mengenai tidak adanya tanggapan dari para tutor dalam kegiatan tutorial. Masalahmasalah lainnya antara lain mengenai kesulitan mencari tutor statistik, masalah sulitnya memperoleh panduan tutor, dan juga mengenai materi/substansi tutorial. Apa yang dipermasalahkan mahasiswa memang dapat dimengerti, karena dengan tutorial tersebut para mahasiswa berharap banyak yaitu dapat memahami materi modul/bahan ajar sehingga mereka benar-benar siap dalam menghadapi ujian.

Dalam konteks Pendidikan Tinggi Jarak Jauh (PTJJ), tutorial adalah sebuah sarana dalam mendiskusikan masalah-masalah yang menyangkut materi perkuliahan yang tidak dapat dimengerti atau tidak dapat dipecahkan pada saat belajar secara berkelompok. Maka tutoriallah tempat mendiskusikan masalah yang dihadapi dalam belajar materi modul. Oleh karenanya, tutorial di anggap sebagai sarana yang sangat membantu mahasiswa dalam memahami materi modul. Bila mencermati perbincangan mereka, maka akan terasa begitu kental kebutuhan mahasiswa untuk dapat mengikuti tutorial dan menyelenggarakan tutorial secara berkelompok atas inisiatif mereka dengan mengundang tutor secara tatap muka. Selain itu, ini mengenai tutorial elektronik, mahasiswa juga mengharapkan agar mereka dapat lebih mudah mengakses materi yang diinginkan, mendapatkan feedback dari dosen mereka, dan dapat melakukan diskusi perkuliahan dengan lancar demi kelulusan mata kuliah yang mereka tempuh.

\section{2) Modul/Bahan Ajar}

Ada beberapa hal yang sangat mendasar yang harus menjadi perhatian terkait dengan modul atau bahan ajar ini. Pertama, ketersediaan modul untuk mata kuliah tertentu di UPBJJ. Ada beberapa modul yang tidak tersedia sehingga mahasiswa kesulitan mendapatkannya, padahal ujian tetap saja berjalan sesuai dengan jadwal, artinya meskipun mahasiswa tidak mendapatkan modul dan tidak dapat belajar tetap saja mereka harus menempuh ujian tanpa melihat apakah mereka memiliki bahan ajar yang dapat dipelajari atau tidak memilikinya. Apabila tidak tersedianya modul itu di UPBJJ yang sangat jauh dari UT pusat, seperti di Manado barangkali masih dianggap masuk akal, meskipun sebenarnya hal ini tidak harus dan tidak boleh terjadi - sebab UT telah mendapatkan ISO Puslaba - dan oleh karenanya terkait dengan pelayanan bahan ajar ini, tidak ada alasan untuk terlambat dalam pengiriman bahan ajar. Bagaimana dapat mengikuti tutorial dengan efektif apabila bahan ajar sebagai acuan untuk tutorial tidak diperoleh oleh mahasiswa? Dengan kata lain, darimana mahasiswa dapat belajar melalui tutorial dengan efektif apabila modul atau bahan ajarnya tidak ada?

Kedua, ini menggembirakan, adalah adanya 'kreativitas' mahasiswa dalam hak 'memperoleh' modul yang mereka butuhkan. Ini terkait erat dengan adanya Forum Komunitas Mahasiswa FISIP-UT di mana melalui forum ini mereka dapat sharing, saling berbagi pengalaman, saling tukar informasi dan dapat bertukar modul dengan mahasiswa lainnya atau dapat menjual modul yang telah dipakainya (modul bekas pakai) kepada mahasiswa lain yang membutuhkan. Di satu sisi, ini sangat membantu mahasiswa yang tidak memiliki dana besar dalam mendapatkan modul-modul yang dibutuhkan. Tetapi, disisi lain, sebenarnya ini 'tidak begitu menguntungkan' secara finansial bagi UT yang seharusnya memperoleh uang penjualan modul dari mahasiswanya. Meskipun hal ini memang sesuai dengan kebijakan UT yang tidak 
mewajibkan mahasiswanya untuk membeli modul, namun bagaimanapun juga dari segi finansial mengurangi pemasukan (income) UT. Tetapi di atas semua itu, hal ini membuktikan bahwa betapa efektifnya sarana komunikasi melalui internet bagi mahasiswa UT.

\section{3) Substansi Materi Modul}

Terkait dengan bahan ajar ini, ada beberapa wacana yang mencuat di dalamnya, antara lain apakah UT menyediakan mata kuliah yang bahan ajarnya dapat di download melalui internet? Ini sebenarnya suatu pemikiran yang visioner meskipun untuk sampai pada realisasinya banyak hal dan kebijakan yang harus dipertimbangkan. Selama ini UT belum melakukan fasilitas downloading bahan ajar melalui internet, meskipun sudah memberikan web-supplement sebagian mata kuliah yang ditawarkan melalui internet. Tetapi untuk bahan ajar utamanya, UT belum melakukannya. Selain itu, ini yang sangat prospektif, terjadi juga diskusi mengenai substansi materi bahan ajar antara dosen dan mahasiswanya. Ternyata, diskusi mengenai materi tidak saja dapat dilakukan melalui tutorial elektronik (tuton) yang selama ini berjalan. Tetapi dapat juga dilakukan melalui sarana ini seperti melalui forum ini. Barangkali melalui forum komunitas ini, diskusi antara dosen dengan mahasiswa atau antar mahasiswa dapat berlangsung secara lebih bebas dan lebih intens lagi. Apabila diskusi melalui tuton ini dibatasi oleh waktu, maka dengan forum ini diskusi dapat dilakukan dengan lebih leluasa dan 'tidak terikat' dengan waktu. Kapan saja mahasiswa mau, kapan saja dosennya berkenan, maka diskusi dapat berlangsung. Sebenarnya diskusi mengenai materi/substansi bahan ajar ini dapat lebih ditingkatkan intensitas dan kualitasnya apabila antara dosen dan mahasiswa sama-sama memegang komitmen yang sama.

\section{4) Cara Belajar}

Melalui beberapa diskusi intens dengan seorang ahli mengenai self-directed learning, dapat ditengarai bahwa cara belajar setiap orang yang akan berlainan antara satu dengan lainnya. Cara mengelola waktu, cara mengikuti tutorial, dan juga cara mengikuti ujian, misalnya, merupakan cara belajar seseorang. Aspek-aspek inilah yang menjadi dasar konsep belajar mandiri. UT yang menerapkan sistem belajar jarak jauh dengan konsep belajar mandirinya, dapat dikatakan sebagai suatu yang relatif baru di dalam dunia pendidikan di Indonesia. Mahasiswa UT, banyak yang belum mengenal, bahwa belum pernah mendengar, konsep belajar mandiri ini. Mereka masih meraba-raba seperti apa sesungguhnya konsep belajar mandiri itu. Pada kesempatan yang berbeda, beberapa mahasiswa yang sempat ditanya mengenai konsep belajar mandiri ini sering kali memberikan jawaban yang menunjukkan bahwa belajar mandiri itu identik dengan belajar sendiri, tanpa dosen, tanpa mahasiswa lain (tidak bersama-sama dengan mahasiswa lain di dalam ruang kuliah). Padahal konsep belajar mandiri ini tidak demikian. Sebab pada prinsipnya belajar mandiri ini begitu terikat dengan schedule, dengan pengaturan waktu yang harus dipatuhi dalam upaya menguasai materi kuliah pada taraf tertentu (mastery learning). Oleh karenanya, sosialisasi mengenai konsep belajar mandiri ini memang harus dilakukan oleh UT secara sinambung, sehingga konsep belajar mandiri dapat dipahami dan diterapkan oleh mahasiswa UT pada umumnya. 
Bila dicermati cara belajar yang diperbincangkan mahasiswa, pada umumnya bertanya mengenai cara bagaimana belajar yang baik, belajar yang sesuai, cara belajar yang efektif dan efisien sebagai mahasiswa UT dalam memahami modul/ bahan ajar. Hal ini menunjukkan bahwa mahasiswa UT selalu terbuka dan berupaya mencari menemukan konsep, menemukan cara-cara belajar yang efektif dan sesuai bagi mereka. Ha ini juga sekaligus menunjukkan bahwa mereka ingin selalu berhasil dengan baik dalam proses belajar mereka. Ada beberapa mahasiswa menyarankan kepada mahasiswa lainnya untuk selalu berdiskusi melalui internet dengan alasan bahwa selain relatif lebih murah bila harus bertemu di suatu tempat dengan mengundang dosen atau tutor, maka internet dianggap sebagai media yang efektif, karena mahasiswa dapat menghemat waktu, tenaga, dan uang dibanding dengan melaksanakan tutorial atap muka.

\section{5) Kurikulum}

Masalah kurikulum menjadi topik diskusi yang paling sedikit (4,94\%), isi perbincangan mahasiswa merujuk kepada sebaran mata kuliah program studi atau suatu jurusan yang ada di lingkungan FISIP-UT. Ada juga mahasiswa yang mengeluhkan-mengenai dua mata kuliah yang di-'merger' (begitu isilah mereka) di mana mereka tidak tahu pasti bahan ajar mana yang dirujuk untuk digunakan di dalam ujian. Untuk hal ini barangkali harus ada kejelasan komunikasi dari pihak UT kepada para mahasiswanya. Informasi mengenai hal ini, barangkali tidak cukup disampaikan kepada UPBJJ di mana UPBJJ-lah yang harus menyampaikan kepada para mahasiswa. Harus ada cara penyampaian pesan yang efektif melalui cara ini sehingga mahasiswa mengetahui betul apa yang menjadi kebijakan UT menyangkut proses perkuliahan mereka. Misalnya, kebijakan mengenai perubahan kurikulum, perubahan mata kuliah (baik 'merger' ataupun penghilangan), pergantian bahan ajar, perubahan jadwal, atau perubahan biaya pendidikan, dsb, sehingga mahasiswa tahu persis apa yang harus dilakukan terkait dengan perubahan berbagai kebijakan yang menyangkut proses perkuliahan mereka. Mahasiswa mempunyai hak untuk mengetahui kebijakan yang dikeluarkan oleh UT terutama yang menyangkut kepentingan mereka selama menjadi mahasiswa UT. Dan sebenarnya, bila hal ini berjalan dengan baik, maka ini menunjukkan bahwa antara UT dengan mahasiswanya telah terjalin hubungan interaktif yang baik dan efektif.

Ada perbincangan yang menarik yang juga menjadi perhatian. Perbincangan ini sungguh menggambarkan bahwa mahasiswa UT juga tidak 'keinggalan kapal' artinya mereka selalu mengikuti perkembangan sosial, politik, ekonomi, kebudayaan, serta berbagai isu yang sedang berkembang (masalah gender, globalisasi, kerawanan sosial, bencana, korupsi, dsb). Hal ini sangat membanggakan, bahwa dengan tingkat intensitas sosial dan interaksi yang rendah, mahasiswa UT masih berupaya mengikuti perkembangan dunia. Dan memang, sebagai seorang mahasiswa yang di tuntut untuk memiliki pandangan dan jangkauan yang luas, maka mahasiswa UT juga telah menunjukkan eksistensinya.

\section{KESIMPULAN}

Mahasiswa FISIP UT yang telah berpartisipasi dalam forum komunitas FISIP UT hanya 479 orang (1.40\%). Rendahnya tingkat partisipasi mereka kemungkinan disebabkan oleh pertama tidak semua mahasiswa dapat melakukan akses internet karena di sekitar tempat tinggal mereka tidak ada fasilitas untuk itu; kedua biaya 
akses internet relatif mahal bagi mahasiswa. Kemudian, dari seluruh dosen FISIP UT (66 orang) yang berada di UT pusat, hanya 16 orang (24.24\%) yang menanggapi diskusi, keluhan, atau persoalan yang di hadapi mahasiswa. Rendahnya tingkat partisipasi dosen ini dapat disebabkan: pertama tidak hanya kewajiban dosen untuk berpartisipasi dalam forum; kedua dosen merasa bahwa bukan kapasitas mereka untuk memberikan jawaban atas pertanyaan atau persoalan yang dihadapi mahasiswa.

Seluruh topik diskusi yang masuk pada forum komunitas FISIP UT adalah 1201 buah. Topik diskusi mahasiswa dapat dikategorikan ke dalam tiga topik diskusi besar yaitu (a) topik diskusi yang bersifat administratif (mencakup registrasi, nilai/ujian, yudicium, wisuda, biaya kuliah, alih kredit, TM/LM, beasiswa, dan ijazah); (b) topik diskusi yang bersifat akademik (mencakup tutorial, modul/bahan ajar, substansi modul, TAP/UKT, kurikulum; dan (c) topik diskusi lain-lain (mencakup akreditasi UT, kegiatan kemahasiswaan, interaksi personal, dan pembentukan social formation). Kecenderungan topik diskusi yang paling intens dibicarakan mahasiswa adalah mengenai interaksi personal (25.90\%), masalah-masalah umum (14.24\%), nilai/ujian (11.91\%), tutorial (10.99\%), modul (6.58\%), substansi materi (4.08\%), cara belajar (4.08\%), TAP/UKT (4.00\%), TM/LM (3.41\%), registrasi (3.41\%), wisuda (2.33\%), kurikulum (1.58\%), akreditasi $(1.58 \%)$, beasiswa $(0.92 \%)$, biaya kuliah $(0.58 \%)$, alih kredit $(0.42 \%)$, serta ijazah (0.17\%). Tingginya persentasi pada aspek interaksi personal karena mahasiswa UT memang membutuhkan sarana untuk berkomunikasi dan berinteraksi yang sangat jarang mereka temukan selama ini. Oleh karena itu, mahasiswa benar-benar memanfaatkan forum ini sebagai sarana untuk berkomunikasi dan berinteraksi.

Perbincangan mahasiswa UT juga terkait dengan masalah yang up to date, seperti masalah ekonomi, sosial, politik ataupun kebudayaan. Hal ini membuktikan bahwa mahasiswa UT ternyata tidak ketinggalan dalam mengikuti berbagi perkembangan isu aktual yang merebak di negeri ini, meskipun interaksi yang terjadi diantara mereka tidak seintens mahasiswa perguruan tinggi tatap muka.

\section{DAFTAR PUSTAKA}

Andriani, D. 2003. "Sistem Pendidikan Jarak Jauh Untuk Pendidikan Tinggi yang Berkualitas", dalam E-Learning Dalam Pendidikan, Jakarta, Universitas Terbuka.

Bintari. A. 2006. Analisis Isi Surat Fitur Forum Tanggapan" Pada Pelaksanaan Tutorial Elektronik Di Universitas Terbuka. (Laporan Penerbitan), Jakarta, tidak diterbitkan.

Harian Jawa Pos. 2006. 11 Juli

Keegan. 1991. Foundations Of Distance Education, Biddles Ltd. Great Britain.

Kristiadi. 2003. Potensi telematika dalam peningkatan akses dan kualitas pembelajaran. Makalah disampaikan pada Seminar Nasional Teknologi Pembelajaran di Hotel Inna Garuda Yogyakarta. 
Kusnandar, Ade, Chaeruman, dan Kurniawati, Ika. 2005. ICT Dalam Pendidikan, Jurnal Teknodik. Volume 9, No. 17, Desember

Moleong, J.L. 2000. Metode Penelitian Kualitatif, Bandung, Remaja Rosda Karya.

Padmo,D, dkk. 2004. Teknologi Pembelajaran: Peningkatan Kualitas Belajar Melalui Teknologi Pembelajaran, Jakarta, Pusat Teknologi Komunikasi dan Informasi Pendidikan.

Rakhmat, J. 1993. Metode Penelitian Komunikasi, Bandung, Remaja Rosdakarya.

Sukarsih, Y. 2005. Pemanfaatan Layanan Online di Institusi Pendidikan Jarak Jauh. Volume 6, No. 1 September, hlm. 69-76.

Suparman, A \& Zuhairi, A. 2004. Pendidikan Jarak Jauh Teori dan Praktek, Jakarta, Universitas Terbuka.

Setiawan, B. dan Muntaha, A. 2006. Metode Penelitian Komunikasi, Buku Materi Pokok, Universitas Terbuka.

Tim Uji Coba UT Online. 2002. Buku panduan kuliah online, tutorial online, dan konseling on_line, Jakarta, Universitas Terbuka. 